\title{
A study on diversity and distribution of Ficus L. (Dicotyledonae: Moraceae) species at Forest Research Institute (FRI), Dehradun (Uttarakhand), India
}

\author{
Mukesh Kumar \\ Department of Biotechnology, Maharishi Markandeshwar (Deemed to be University), \\ Mullana-Ambala-133207 (Haryana), India \\ Indu Sharma \\ Department of Biotechnology, Maharishi Markandeshwar (Deemed to be University), \\ Mullana-Ambala-133207 (Haryana), India \\ Praveen Kumar Verma \\ Plant Diversity, Systematics and Herbarium Division, Forest Research Institute (F.R.I.), \\ Dehradun (Uttarakhand), India

\section{Bikram Jit Singh} \\ Department of Mechanical Engineering, Maharishi Markandeshwar (Deemed to be University), \\ Mullana-Ambala (Haryana), India

\section{Raj Singh} \\ Department of Biotechnology, Maharishi Markandeshwar (Deemed to be University), \\ Mullana-Ambala-133207 (Haryana), India \\ Sushil Kumar Upadhyay* \\ Department of Biotechnology, Maharishi Markandeshwar (Deemed to be University), \\ Mullana-Ambala-133207 (Haryana), India \\ ${ }^{*}$ Corresponding author. Email: upadhyay.k.sushil@gmail.com
}

\section{Article Info}

https://doi.org/10.31018/ jans.v13i2.2654

Received: April 2, 2021

Revised: May 13, 2021

Accepted: May 20, 2021

\section{How to Cite}

Kumar, M. et al. (2021). A study on diversity and distribution of Ficus L. (Dicotyledonae: Moraceae) species at Forest Research Institute (FRI), Dehradun (Uttarakhand), India. Journal of Applied and Natural Science, 13(2), 552 - 560. https:// doi.org/10.31018/jans.v13i2.2654

\begin{abstract}
Ficus L., commonly known as Fig, is a member of the family Moraceae (mulberry family) comprises 37 genera and approximately 1,100 species distributed in diverse ecosystems, especially in tropical and temperate regions of the world. The Ficus genus stands out as a keystone resource provider in many tropical forests, which is probably because of continuous nonseasonal fruiting in many species. It is one of the largest genera in the angiosperms about 750 species. The present study was carried out in the Forest Research Institute (FRI) campus, Dehradun (Uttarakhand), India. The phytodiversity of Ficus L. and their socio-economic values worked out during the investigation, religious-spiritual attachment, food of wild animals, ethnomedicinal and timber significance. There were 16 species of Ficus L. recorded from New Forest, FRI, Dehradun based on the morphological observations of taxonomically significant characteristics. The species found in FRI New Forest Dehradun were, Ficus benjamina, F. religiosa, F. racemosa, F. rumphii, F. retusa, F. krishnae, F. elastica, F. virens, F. semicordata, F. auriculata, F. hispida, F. pumila, F. palmata, F. drupacea, F. benghalensis, F. pomifera. Out of the notified 16 species of Ficus, 11 species were trees, 3 shrubs and 2 climbers in nature. The maximum leaf size $\left(30 \times 27 \mathrm{~cm}^{2}\right)$ was reported in $F$. auriculata, followed by $F$. semicordata $\left(28 \times 10 \mathrm{~cm}^{2}\right), F$. benghalensis $\left(25 \times 11 \mathrm{~cm}^{2}\right)$. However, minimum leaf size was noticed in $F$. benjamina $\left(4 \times 2 \mathrm{~cm}^{2}\right)$ and $F$. retusa $\left(4 \times 3 \mathrm{~cm}^{2}\right)$. Among, 15 species, axillary fig (fruit) arrangement was observed, while one species $(F$. racemosa) has stem position of fruits. The current finding is itself a pioneer study to present a glimpse of such immense species diversity of single genera from sub-valley areas and will be a milestone for future studies in conservation and management of these wild varieties.
\end{abstract}

Keywords: Ficus L., Key-stone, Fig, Axillary fig, Dicotyledonae, Moraceae, Diversity

\section{INTRODUCTION}

Plants are known as producers and important for reduction of pollution level. These are also a foremost source of energy by trapping solar radiations to convert in to chemical energy in their photosynthesis activity. Linnaeus (1753) proposed the genus Ficus for the first time. The Latin word Ficus is derived from the Indian 
'Fag' from which come the Italian, Portugese and the Spanish 'Figs', the French 'Figsee' and the German 'Feigen' and the Dutch 'Rijig' (Masilamoney, 1984). Hooker (1888) gave an account of 112 species for the Indian sub-continent including Pakistan and Bangladesh). King (1887) described nearly 220 species with excellent plates in his book "Magnum opus on IndoMalayan figs". Fischer (1928) gave a brief account on 30 species of Ficus for the erstwhile lie Madras Presidency. Available literature traces the importance of $\mathrm{Fi}$ cus even from 256 B.C. It is said to be the tree under which Buddha achieved enlightenment 2500 years ago (Gadgi, 1996). Since the peepal considered as an incarnation of Vishṇu or Buddha and have spiritual attachment with this tree. Tree worship on Saturday of every week constructing stone plate form around the tree, and tree marriage of peepal to bargad ( $F$. benghalensis) is a special culture demonstrating our love with trees. The family Moraceae (mulberry family) comprises 37 genera and approximately 1,100 species distributed in diverse ecosystem especially in tropical and temperate regions of the worldare eaten by insects, birds and animals throughout the year (Chaudhary et al., 2012).

It is one of the largest genera in the angiosperms, about 755 species worldwide (Chaudhary et al., 2012; Sharma et al., 2016). The genus is distributed throughout the world primarily in subtropical and tropical regions (Berg and Corner, 2005). Around 511 of these are occurring in Indo-Australasian region (Asia, Malaysia, Pacific Island and Australia) and approximately 132 species in Neotropical region (Central and South America) (Berg, 2003; Berg and Corner, 2005; Kumar et al., 2018). In India, the Banyan tree ( $F$. benghalensis) is being cultivated as an avenue tree along roadsides for generations. The different species of Ficus are known for their pharmacological and ethnomedicinal properties and used in modern medicine and pharmaceutical applications (Adebayo et al., 2009; Abdulla et al., 2010; Sharma et al., 2016). F. racemosa applied profoundly for the treatment of wound healing and skin cancer (Lalla, 2005; Singh et al., 2019). The fruit extracts of $F$. benjamina, $F$. benghalensis and $F$. religiosa have significant antimicrobial and antibacterial activities (Mousa et al., 1994; Sharma et al., 2016; Singh et al., 2020a,b,c). The aqueous extract of fruit and bark ( $F$. religiosa) possess potent anthelminthic effect includes parasitic round worm Ascaridia galli, etc. (Tiwari et al., 2014; Upadhyay, 2016a,b,c; Tiwari and Talreja, 2020). The ethnomedicinal significance of trees, shrubs and climbers was also evaluated and reported yesteryears investigation by different schools (Aggarwal et al., 2020; Devi et al., 2020; Sharma et al., 2020; Singh et al., 2019; Singh et al., 2020c,d,e).

The first systematic account of the Indian Ficus L. is available in King $(1887,1888)$ and recorded 113 species and 47 infra-specific taxa from whole British India. Only 75 species and 16 infra-specific taxa were reported from the present political boundary of India. However, till date no separate account of the Indian species of Ficus except some scattered works (Rani 1985; Shree Kumar, 1998; Priyadarsana, 1999; Kumar et al., 2011; Chaudhary et al., 2012). Therefore, the present study was designed to carry out phytodiversity and distribution of Ficus L. in the Forest Research Institute (FRI) campus, Dehradun (Uttarakhand), India on the basis of significant morphotaxometric assessment including tree habits, leaves shape, leaves size, fruiting positions etc. The socioeconomic and ethnomedicinal values of the recorded 16 species were documented as well during this investigation.

\section{MATERIALS AND METHODS}

\section{Site of investigation}

Present study on the phytodiversity and distribution of Ficus L. (Dicotyledonae: Moraceae) based on the scientific survey done at Forest Research Institute (FRI), Dehradun (Uttarakhand), India (Fig. 1). The vegetation is deciduous and evergreen spread over more than 1100 acre noncultivated sub-valley circumference of campus and presently known as New Forest.

\section{Geolocation and area of site}

It is situated between $\mathrm{N} 30^{\circ} 20^{\prime} 31.56$ " Latitude and Longitude $E 77^{\circ} 59^{\prime} 50.28^{\prime \prime}$ having expansion stretch up to $4.45 \mathrm{~km}^{2}$. The climate is marked by hot summer, well distributed rainfall $[7.7 \mathrm{~mm}-686.4 \mathrm{~mm}(360 \pm 109.6 \mathrm{~mm})]$ during South-West Monsoons and cold winter with small amount of winter rain.

\section{Survey and study of phytodiversity}

The overall campus thoroughly surveyed viz. Beeson Road, Canning Road, Chaturvedi Road, Circular Road, Parker Road, Takle Road, Hospital Road, Howard Road, Tierman Road, Lace Road, Teak Road, Trevor Road, Troup Road, Shalich Road, Rao Road, Hart Road, Mason Road, and Wilmot Road after onsite in situ morphological examination followed by validation of the taxonomic position through comparative analysis using available keys and herbarium to the plant taxonomy housed in Systematic Botany Discipline, FRI, Dehradun. The wild as well as cultivated plant species of the family have been considered for study as the vegetation of this campus is mostly planted. Under each species, the complete citation, synonyms, short description, phenology, common name and English name and economic importance of every species have been provided (Table 1).

\section{RESULTS}

The findings of the present study done in New Forest campus of Dehradun indicated the campus abundant of 


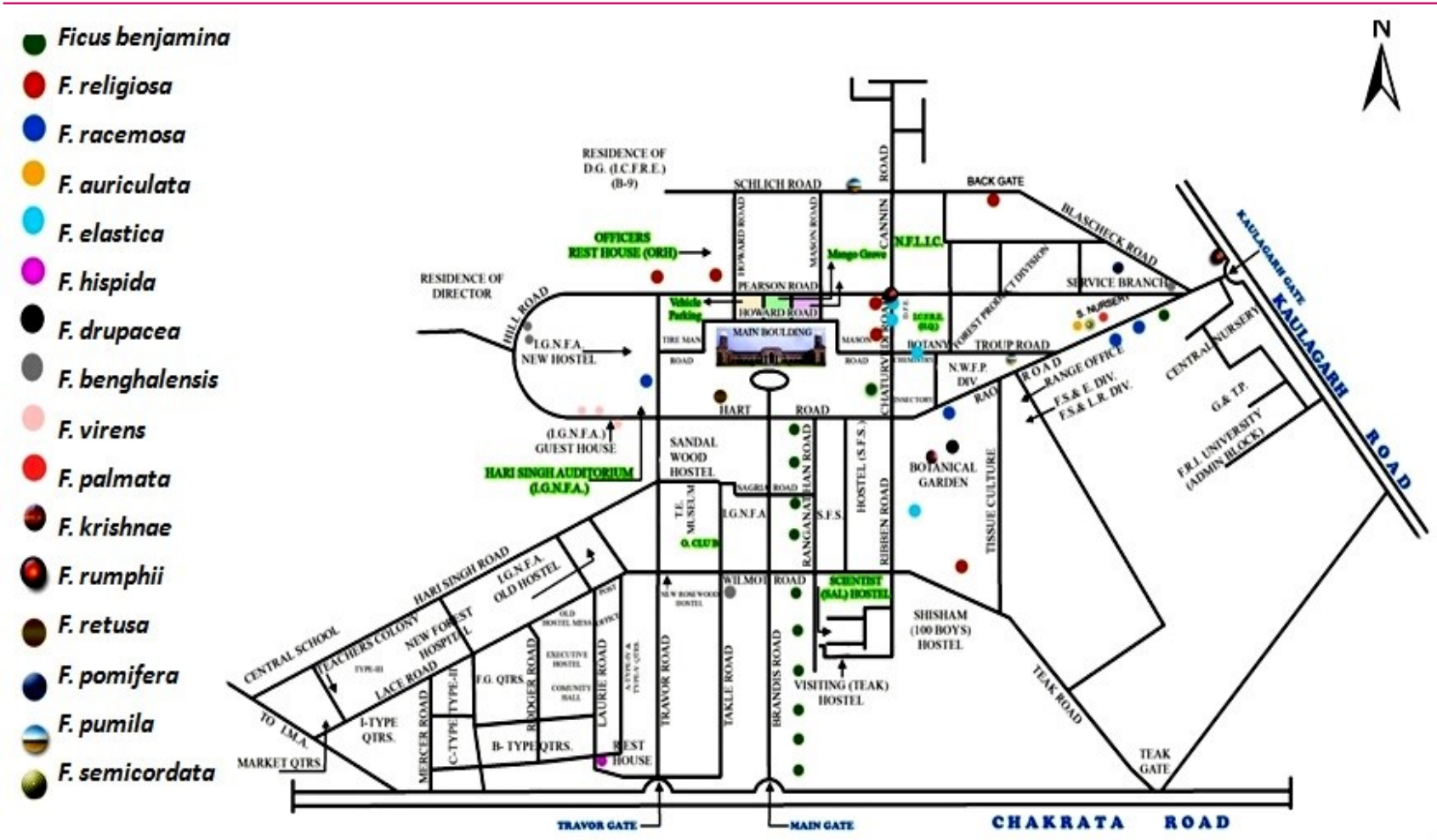

Fig. 1. Map showing site of investigation and distribution of Ficus L. phytodiversity in Forest Research Institute (FRI), Dehradun (Uttarakhand).
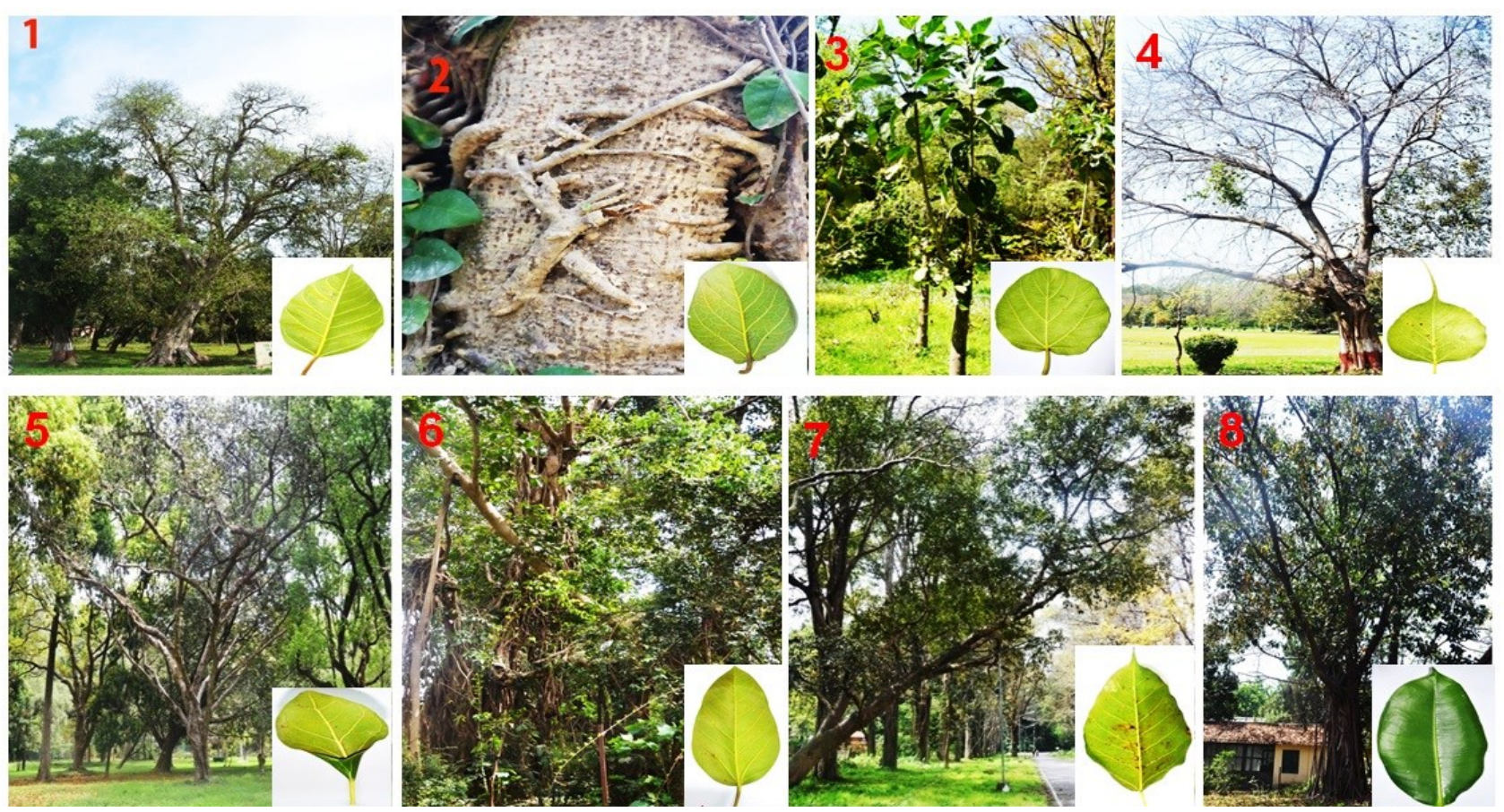

Fig. 2. Phytodiversity of Ficus sp.: (1) F. racemosa, (2) F. pumila, (3) F. auriculata, (4) F. religiosa, (5) F. krishnae, (6) F. benghalensis, (7) F. virens, (8) F. elastica.

Ficus species wild and planted. Out of 16 species, it was found that Ficus racemosa, F. auriculata, F. pomifera, F. rumphii, F. palmata var. vigrata, F. benghalensis, F. hispida, F. virens and F. religiosa mostly growing as a wild population. On contrary $F$. drupacea, $F$. pumila, F. benjamina, F. elastica, F. krishnae, F. retusa and $F$. semicordata are planted as avenue plan- tation (Figs. 2,3; Table 1). Out of studied species, one species was found as straggler shrubs ( $F$. pumila) and the remaining species were small tree to big free standing trees. During investigation, several figs were good examples of parasitism as strangler ( $F$. benghalensis, F. religiosa, F. virens, F. racemosa, F. benjamina, F. rumphii). 


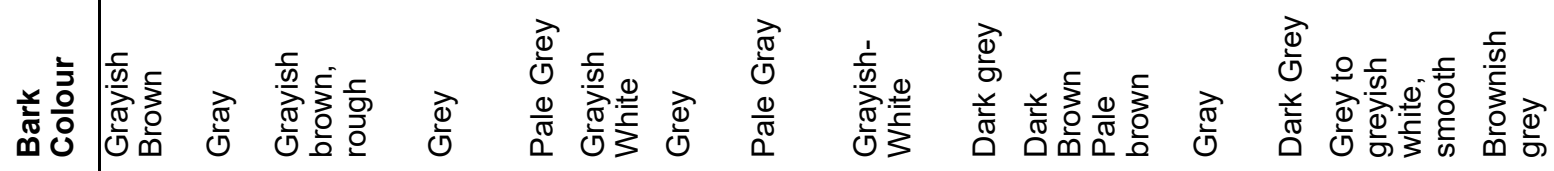

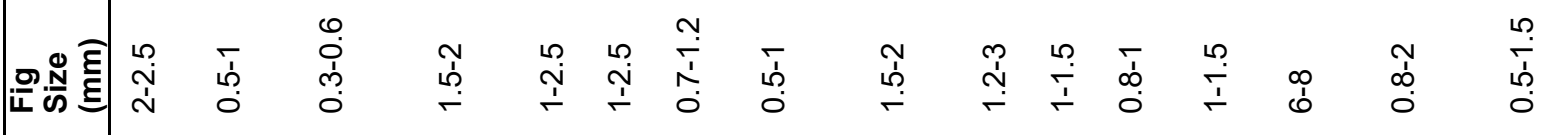

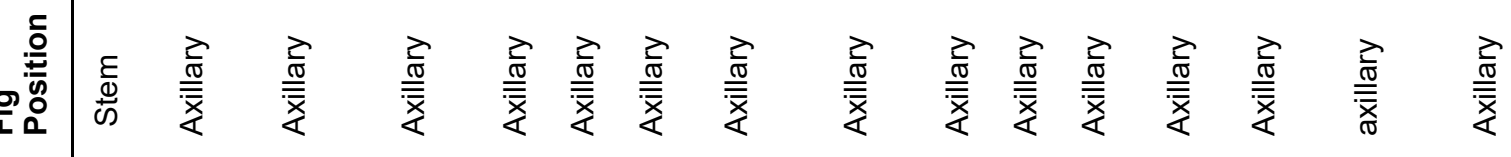

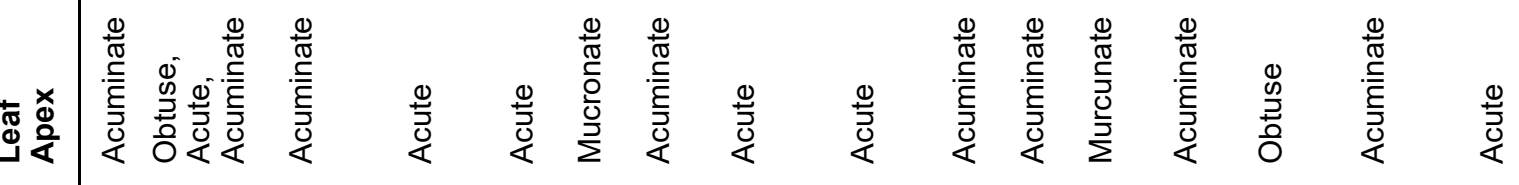

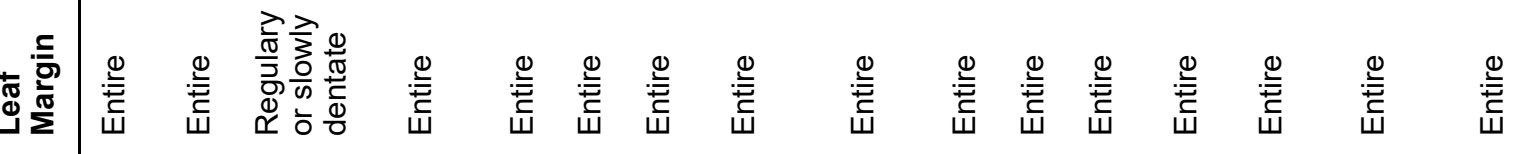

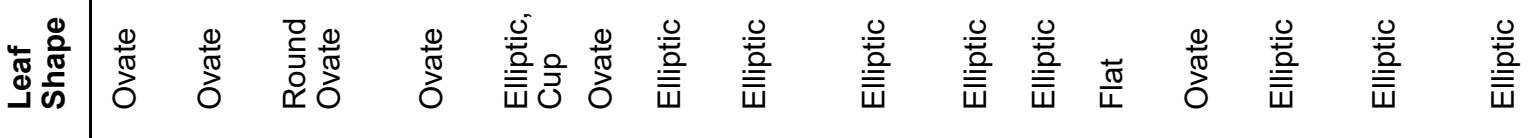

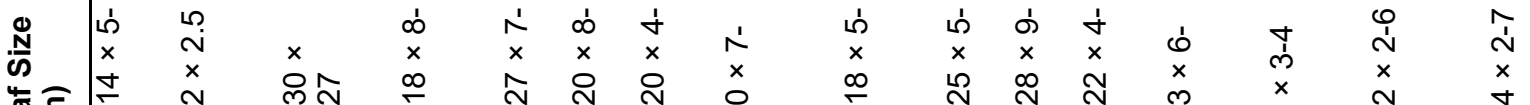

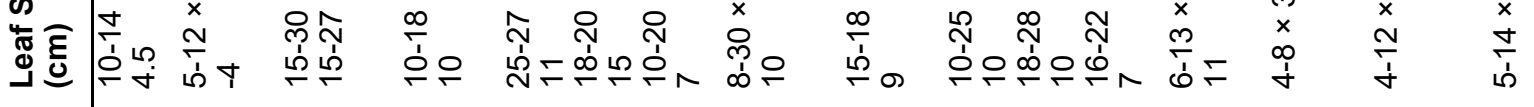
.0․․․

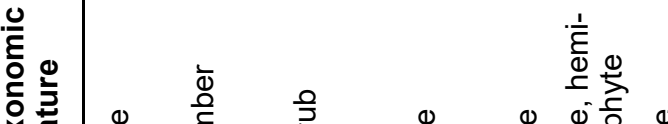

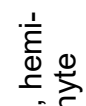

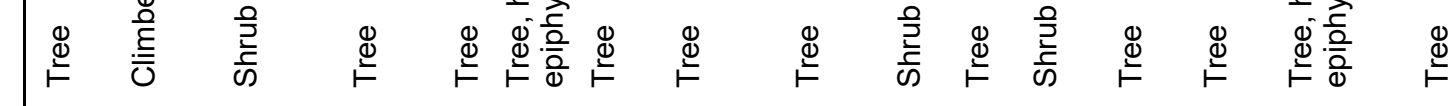

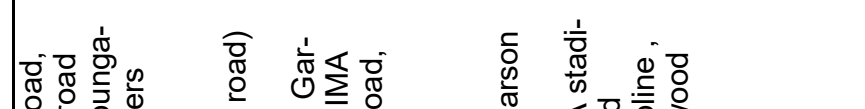

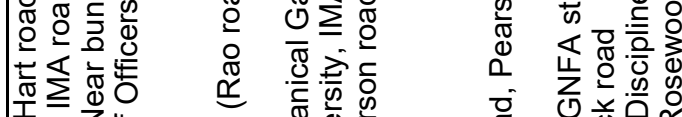

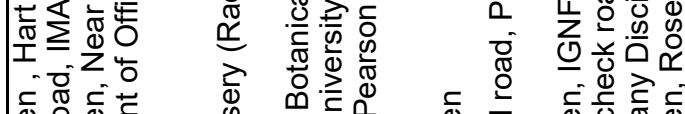

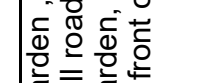

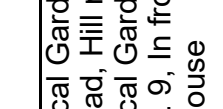

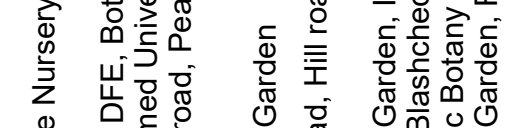

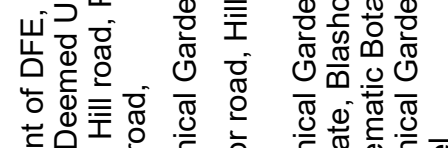

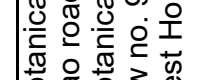

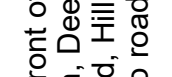

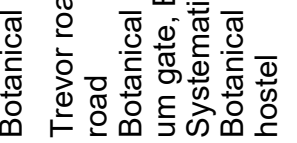

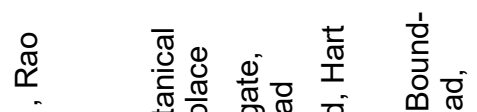
๓ᄄ口 므 뚜

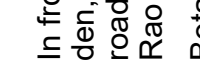




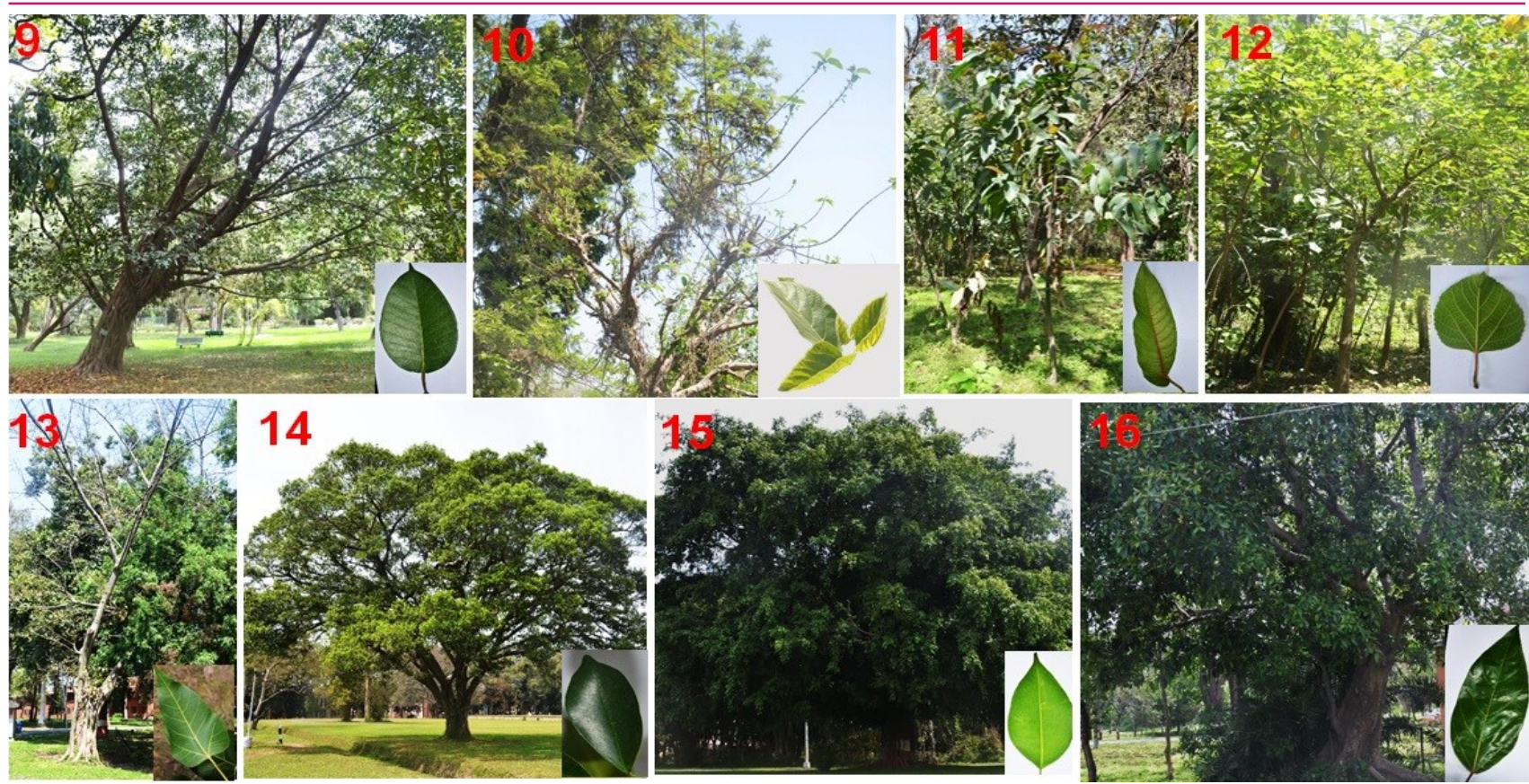

Fig. 3. Phytodiversity of Ficus sp.: F. drupacea (9), F. hispida (10), F. semicordata (11), F. palmata (12), F. rumphii (13), F. retusa (14), F. benjamina (15), F. pomifera (16).

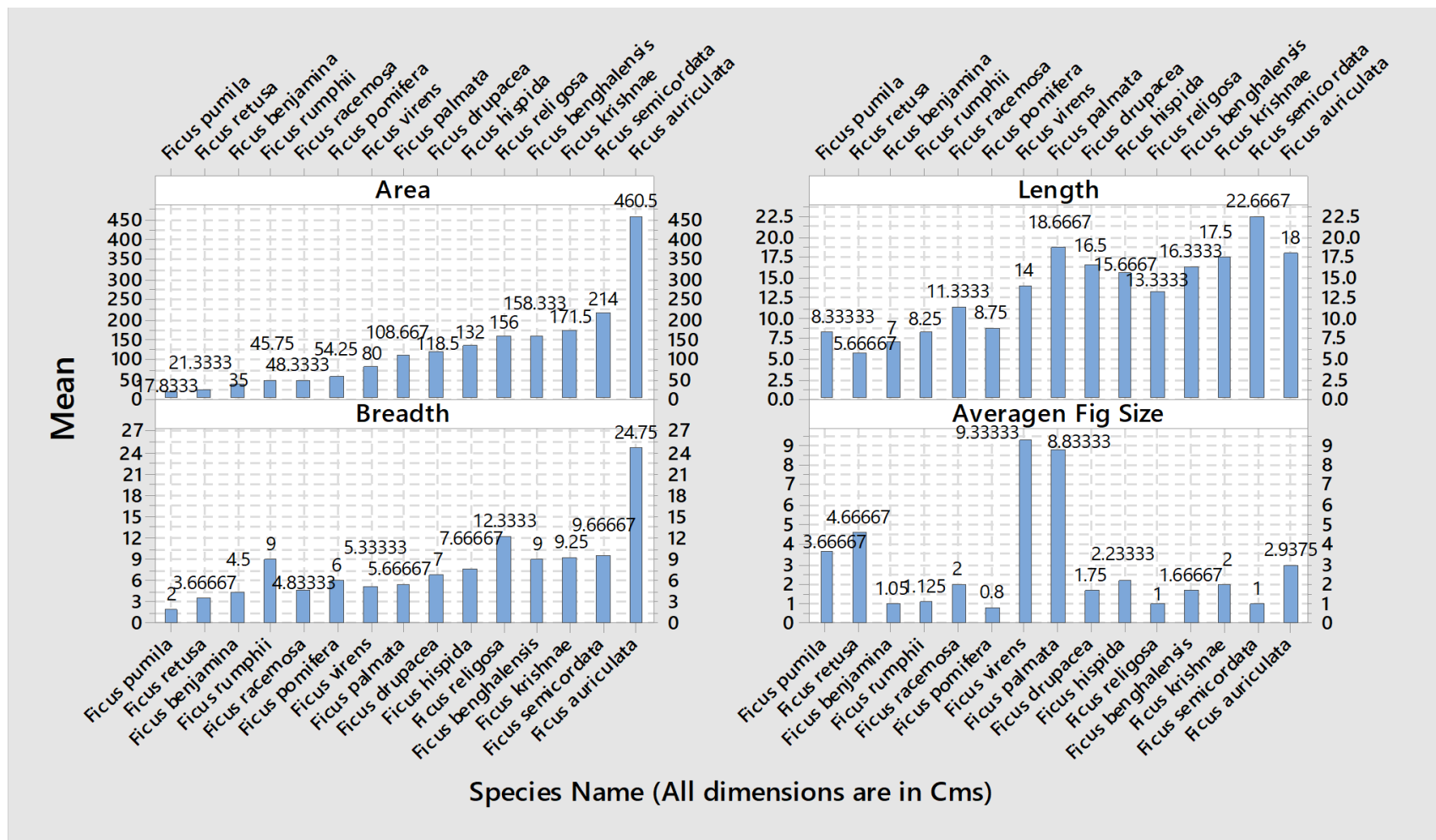

Fig. 4. Leaf area, length, breath and fig size of the different Ficus species.

The Ficus exhibited and characterized by alternate stipulated leaves (with 'pearl glands' or without 'pearl glands) with distinct stipule and milky latex in all parenchymatous tissues. Cystoliths were very commonly present (especially in the epidermis, variable in size and shape). The 'flowers' of Moraceae are often pseudanthia (reduced inflorescences). The functionally fertile male and female flowers have axillary inflorescences; mostly with the small flowers packed into spikes, in heads orhollow receptacles, on disks etc. with or without involucral bracts and pseudanthial, or nonepseudanthial. Flowers small (reduced); regular; cyclic with monoecious, or dioeciouslineages. Fruit fleshy, or non-fleshy; indehiscent; a drupe, or achene like; enclosed in the fleshy receptacle (often, and the inflorescence axis often constituting a common 


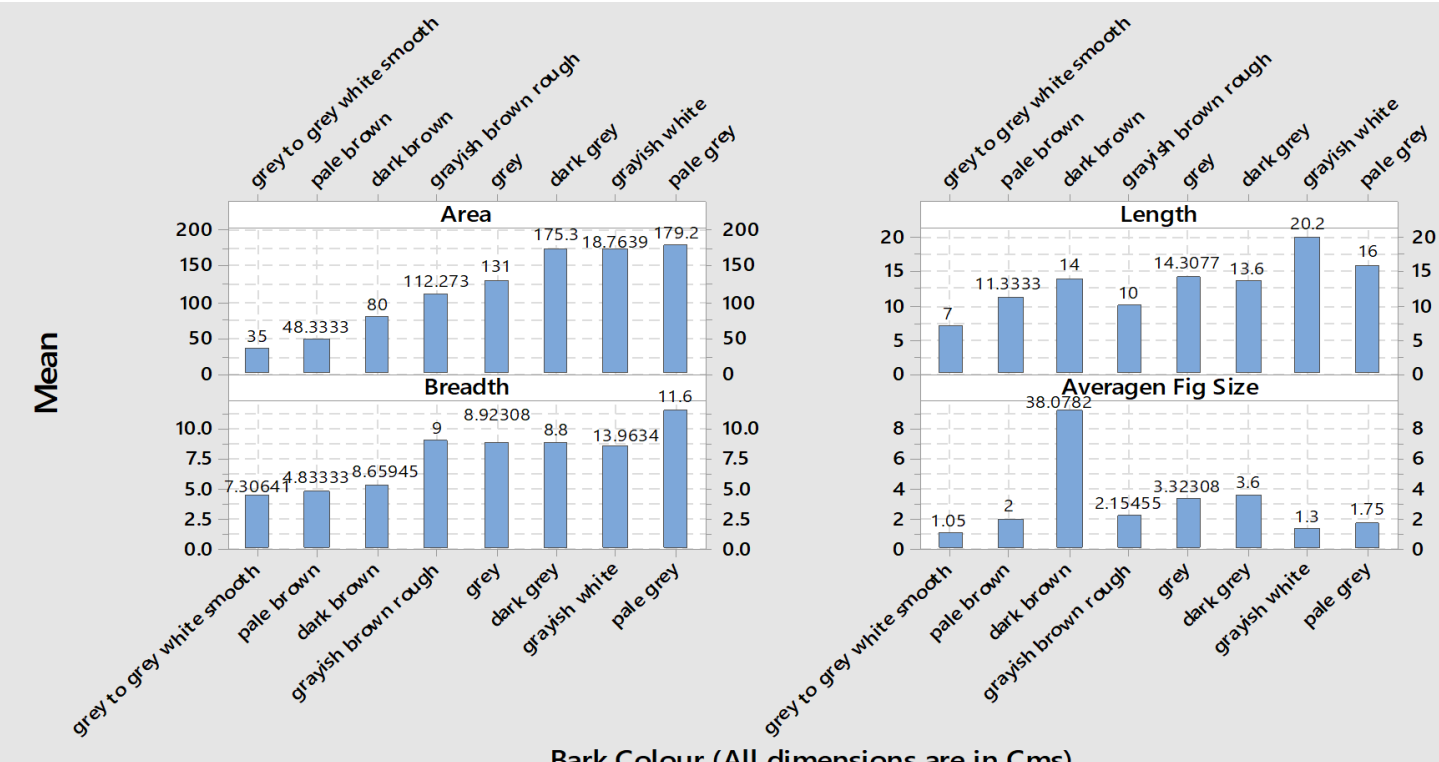

Bark Colour (All dimensions are in $\mathrm{Cms}$ )

Fig. 5. Leaf area, length, breath and fig size on the basis of the leaf colours of different Ficus species.

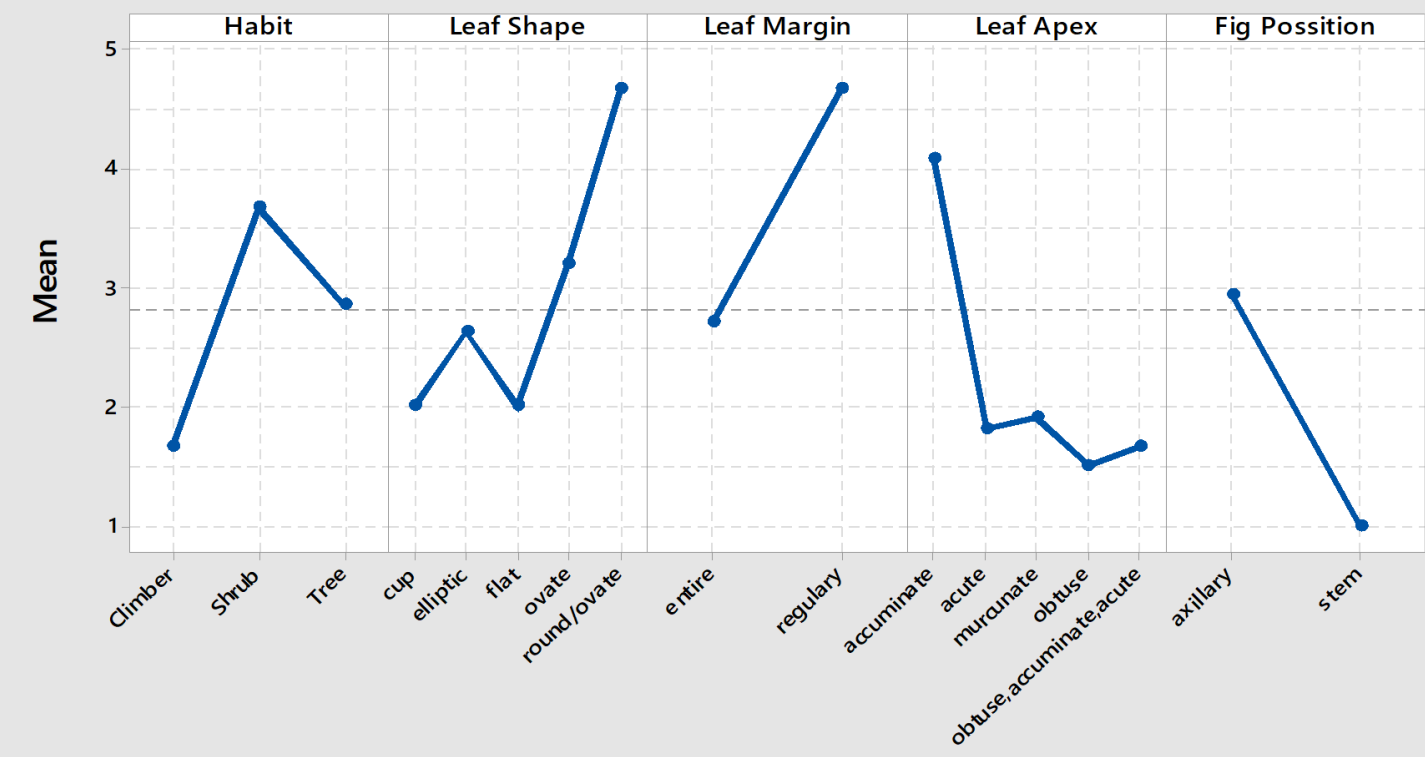

Fig. 6. Fig size according to the habit, leaf shape, margin, apex and fig position in different Ficus species.

fleshy receptacle), or without fleshy investment external to the original ovary. The drups with one stone and gynoecia of adjoining flowers combined to form a multiple fruits (frequently), or not forming a multiple fruits. The maximum leaf size $\left(30 \times 27 \mathrm{~cm}^{2}\right)$ was reported in $F$. auriculata, followed by $F$. semicordata $\left(28 \times 10 \mathrm{~cm}^{2}\right), F$. benghalensis $\left(25 \times 11 \mathrm{~cm}^{2}\right)$. However, the minimum leaf size was recorded in $F$. benjamina $\left(4 \times 2 \mathrm{~cm}^{2}\right)$, and F. retusa $\left(4 \times 3 \mathrm{~cm}^{2}\right)$ (Figs. 4,5$)$. Out of 16 species of Ficus, 11 species were trees, 3 shrubs and 2 species climbers in nature (Table 1 ). Out of 16 species, 15 species having axillary fig (Fruit) arrangement and one species with stem position (F. racemosa).

\section{DISCUSSION}

A large number of works have been carried out either at regional or global levels for the systematics and distribution of Fiscus L., but the literature on confined locality scares (Corner, 1975, 1981; Kochummen, 1998; Chang and Wu, 1998; Berg, 2001, 2003, 2004, Dixon, 2003; Wu et al., 2003; Berg and Corner, 2005; Berg et al., 2006; Tzeng et al., 2009). The yesteryears studies bringing substantial changes in identification, circumscription, nomenclature, distributional pattern and socioeconomic significance of the of the selected species which corroborated to the current findings at FRI campus (King 1887, 1888; Tzeng et al., 2009; Chaudhary et 


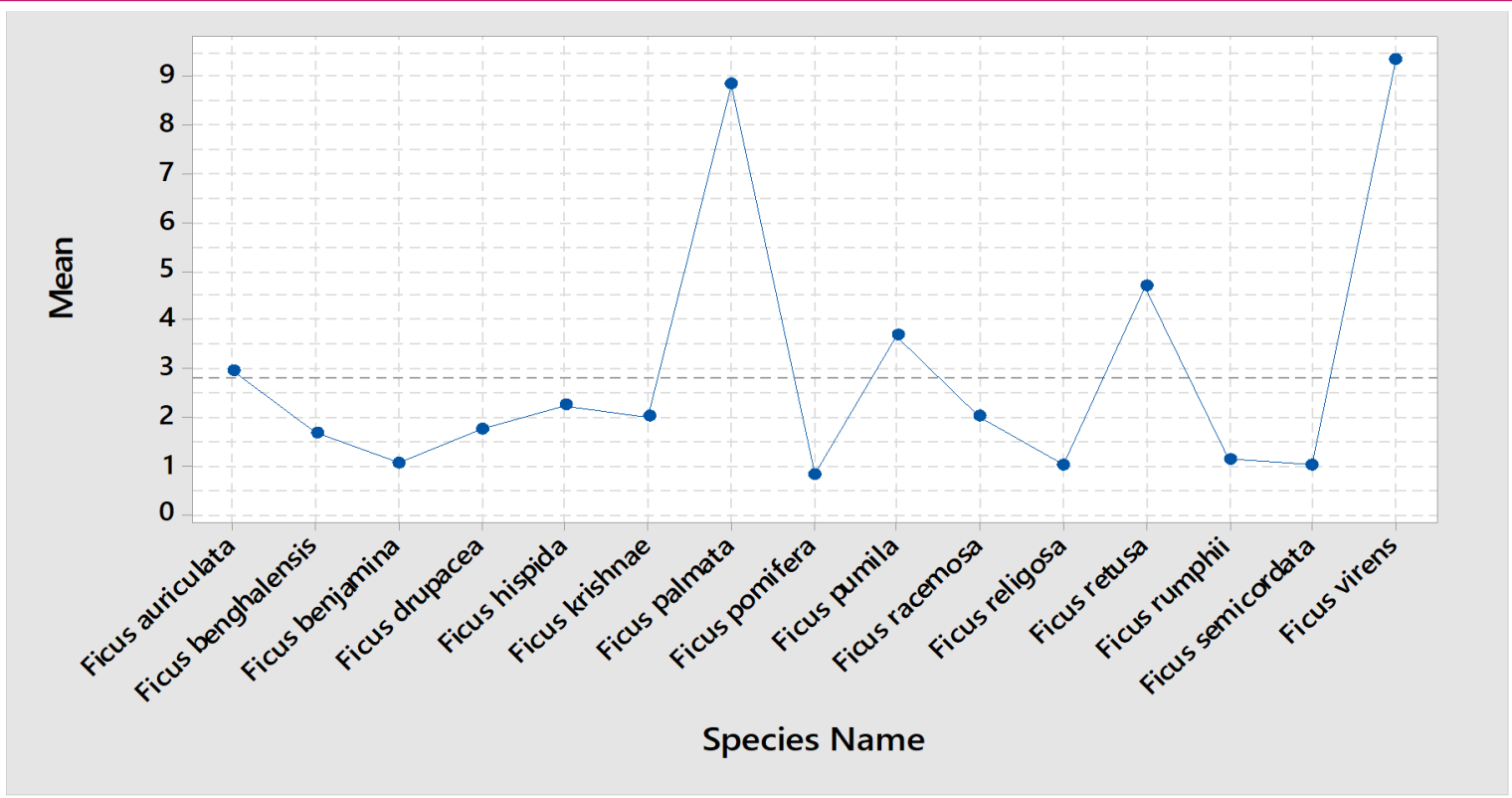

Fig. 7. Fig size of different Ficus species of the study area.

al., 2012; Doharey et al., 2021; Singh et al., 2021a,b). Ficus (Moraceae) is arguably one of the most important plant genera in the campus of FRI., Dehradun. The findings reflected 10 wild native species of Ficus L. viz., $F$. racemosa, $F$. virens, $F$. benghalensis, $F$. auriculata, F. pomifera, F. semicordata, F. palmata subsp. virgata, F. hispida, F. religiosa, F. rumphii and 6 planted exotic species including $F$. krishnae, $F$. benjamina, F. retusa, $F$. pumila, F. drupacea and F. elastica (Molbo et al., 2003; Machado et al., 2005; Kislev et al., 2006; Kumar et al., 2012; Moustafa, 2020; Mustafa et al., 2020).

The plantation of Ficus L. was adequate to dot every road on the FRI campus with at least one species. Plant habits ranged from shrubby pioneers 1 to 2 meters ( $F$. hispida), through small $(F$. palmata subsp. virgata), to emergent trees ( $F$. religiosa, $F$. benjamina, $F$. benghalensis, etc.), climbers ( $F$. hederacea and $F$. pumila) and hemiepiphytes ( $F$. religiosa, $F$. virens, $F$. benjamina, $F$. racemosa and $F$. benghalensis). Members of this genus were difficult to distinguish by their flowers but can be differentiated by habit, leaf shape, and their figs (Whistler, 2000). In the present study, the authors found that the largest fig size was $6-8 \mathrm{~mm}(F$. retusa). However, smallest size 0.3-0.6 $\mathrm{mm}$ ( $F$. auriculata) was documented (Fig. 6-7). The leaf shape of $F$. krishnae was cup shaped, which shows the unique feature of the Ficus species and also known as makhankatori.

\section{Conclusion}

Ficus L. is a keystone species in the ecosystem because its fruit is beneficial for birds, insects and animals. Fruits are nutritious, energetic, healthy and having socio-economic and ethno-medicinal values as well.
There are 16 Ficus species recorded from New Forest FRI campus Dehradun. Among them, 10 were native wild species; however, 6 planted non-native species were documented during the present investigation. The current finding is a pioneer study to present a glimpse of such immense species of single genera from the sub -valley area. There are 11 species recorded as trees, 3 shrubs and 2 climbers inhabit. Most of the observed species had axillary fruit arrangement, while one species $F$. racemosa with stem position. These plants are promising candidates in ethno-pharmaceutical biology to develop and formulate new drugs to future clinical uses. Therefore, more pre-clinical and clinical studies for establishing better quality control methods must be conducted to elucidate the unexplored potential of these plants.

\section{ACKNOWLEDGEMENTS}

The author Mukesh Kumar is grateful to my supervisor Dr. Praveen Kumar Verma, Scientist B Systematic Botany Discipline, Forest Botany Division, Forest Research Institute (FRI), Dehradun, and Internal supervisor Dr. Indu Sharma, Associate Professor Department of Biotechnology, Maharishi Markandeshwar (Deemed to be University), Millana-Ambala (Haryana) for able guidance.

\section{Conflict of interest}

The authors declare that they have no conflict of interest.

\section{REFERENCES}

1. Abdulla, M.A., Ahmed, K.A.A., Luhoom, F.M.A. \& Muhanid, M. (2010). Role of Ficus deltoidea extract in the en- 
hancement of wound healing in experimental rats. Biomedical Research, 21 (3), 241-245.

2. Adebayo, E.A., Ishola, O.R., Taiwo, O.S., Majolagbe, O.N. \& Adekeye, B.T. (2009). Evaluations of the methanol extract of Ficus exasperate stem bark, leaf and root for phytochemical analysis and antimicrobial activities. African Journal of Plant Science, 3(12), 283-287.

3. Aggarwal, D., Upadhyay, S.K., Singh, R., Sehrawat, N., Yadav, M., Singh, M. \& Kumar, V. (2020). Tissue culture propagation of Bacopa monnieri (L.) Pennell: An important medicinal plant. Advances in Bioresearch, 11(5), 97-103. https://doi.org/10.15515/abr.0976-4585.11.5.97103.

4. Berg, C.C. \& Corner, E.J.H. (2005). Moraceae - Ficus Flora Malesiana Series 1 (Seed Plants). National Herbarium of the Netherlands, 17(2), 1-730.

5. Berg, C.C. (2001). Flora neotropica monograph 83: Moreae, Artocarpeae, Dorstenia (Moraceae) with introductions to the family and Ficus and with additions and corrections to flora neotropicamonograph 7. The New York Botanical Garden, Bronx, NY. pp. 1-346

6. Berg, C.C. (2003). Flora Malesiana precursor for the treatment of Moraceae 1: The main subdivision of Ficus: The subgenera. Blumea, 48, 167-178. https:// doi.org/10.3767/000651903X686132.

7. Berg, C.C. (2004). Flora Malesiana precursor for the treatment of Moraceae 6: Ficus sub-genus Sycomorus. Blumea, 49, 155-200. https://doi.org/10.3767/0006519 04X486278.

8. Berg, C.C., Corner, E.J.H. \& Jarrett, F.M. (2006). Moraceae (Genera other than Ficus). Flora Malesiana Series 1 (Seed Plants) National Herbarium of the Netherlands, 17 (1), 1-152.

9. Chang, S.S. \& Wu, C.Y. (1998). Moraceae. In: Flora Reipublicae Popularis Sinicae (eds., Chang, S.S. \& Wu, C.Y.), 23, 1-219.

10. Chaudhary, L.B., Sudhakar, J.V., Kumar, A., Bajapai, O., Tiwari, R. \& Murthy, G.V.S. (2012). Synopsis of the genus Ficus L. (Moraceae) in India. Taiwania. 57(2), 193-216. https://doi.org/10.6165/tai.2012.57(2).193.

11. Corner, E.J.H. (1975). New taxa of Ficus (Moraceae). Blumea, 22, 299-309.

12. Corner, E.J.H. (1981). Moraceae. In: A revised handbook to The Flora of Ceylon (ed., Dassanayake, M.D.), Oxford and IBH, New Delhi, India. 3, 230-279.

13. Devi, A., Dahiya, V.S., Upadhyay, S.K. \& Singh, R. (2020). Antimicrobial acitivity and phytochemical constituents present in Syzium cumini (L) seed, leaves and bark extract. Plant Archives, 20(2), 7787-7790.

14. Dixon, D. J. (2003). A taxonomic revision of the Australian Ficus species in the section Malvanthera (Ficus subg. Urostigma: Moraceae). Telopea 10, 125-153.

15. Doharey, V., Kumar, M., Upadhyay, S.K., Singh, R. \& Kumari, B. (2021). Pharmacognostical, physicochemical and pharmaceutical paradigm of ash gourd, Benincasa hispida (Thunb.) fruit. Plant Archives, 21(1), 249-252. https://doi.org/10.51470/ PLANTARCHIVES.2021.v21.S1.041.

16. Gadgi, M. (1996). Documenting diversity: An experiment. Current Science, 70, 36.

17. King, G. (1887). The species of Ficus of the Indo-Malayan and Chinese countries. Annals of Royal Botanical Garden, Calcutta, 1, 1-185.
18. King, G. (1888). Ficus L. In: The Flora of British India (ed. Hooker, J.D.). L. Reeve \& Company, London. 5, 494-537.

19. Kislev, M.E., Hartmann, A. \& Bar-Yosef, O. (2006). Response to comment on early domesticated fig in the Jordan valley. Science, 314 (5806), 1683b. https:// doi.org/10.1126/science.1133748.

20. Kochummen, K.M. (1998). New species and varieties of Moraceae from Malaysia. Garden Bulletin of Singapore, 50, 197-219.

21. Kumar, A., Bajpai, O., Mishra, A.K., Sahu, N., Behera, S.K. \& Chaudhary, L.B. (2011). Assessment of diversity in the genus Ficus L.(Moraceae) of Katerniaghat wildlife sanctuary, Uttar Pradesh, India. American Journal of Plant Sciences, 2(01), 78.

22. Kumar, S., Dimple, A., Tomer, V., Gat, Y. \& Kumar. V (2018). Ficus religiosa: A wholesome medicinal tree. Journal of Pharmacognosy and Phytochemistry, 7(4), 32-37.

23. Lalla, J.K. (2005). Herbal medicines revisited. The Pharma Review, 12, 101-105.

24. Linnaeus, C. (1753). Species Plantarum volume 1 \& volume 2. L. Salvi, Stockhlom.

25. Machado, C.A., Robbins, N., Gilbert, M.T.P. \& Herre, E.A (2005). Critical review of host specificity and its coevolutionary implications in the fig/fig-wasp mutualism. Proceedings of the National Academy of Sciences, 102(1), 6558-6565. https://doi.org/10.1073/pnas.0501 840102.

26. Molbo, D., Machado, C.A., Sevenster, J.G., Keller, L. \& Herre, E.A. (2003). Cryptic species of fig-pollinating wasps: Implications for the evolution of the fig-wasp mutualism, sex allocation, and precision of adaptation. Proceedings of the National Academy of Sciences, 100(10), 5867-5872. https://doi.org/10.1073/ pnas. 0930903100 .

27. Mousa, O., Vuorela, P., Kiviranta, J., Wahab, S.A., Hiltohen, R. \& Vuorela, H. (1994). Bioactivity of certain Egyptian Ficus species, Journal of Ethnopharmacology, 41, 7176. https://doi.org/10.1016/0378-8741(94)90060-4.

28. Moustafa, A.A (2020). A threatened introduced species (Ficus benghalensis L.) in Ismailia, Egypt. Intech Open, https://doi.org/10.5772/intechopen.8.

29. Mustafa, I., Rohmah, N.I., Jono, S., Jatmiko, Y.D. \& Siswanto, D. (2020). The potency of endophytic bacteria isolated from Ficus septica as phytoremediation promoting agent of $\mathrm{Cr}(\mathrm{VI})$ contaminated soil. Biodiversitas. Journal of Biological Diversity, 21(5), https://doi.org/10.13057/ biodiv/d210519.

30. Priyadarsana (1999). Ficus superb Miq. and F. fergusoni (King) Worthington (Moraceae): Two new reports from India. Journal of Bombay Natural History Society, 96, 492-493.

31. Rani, N. (1985). Ficus Ibipila (Miq.) King (Moraceae)- A new record for India. Journal of Bombay Natural History Society, 82, 235-237

32. Sharma, A.K., Sharma, V., Sharma, V., Sharma, J.K. \& Singh, R. (2020). Multifaceted potential of Eichhornia crassipes (Water Hyacinth) ladened with numerous value aided and therapeutic properties. Plant Archives, 20(Spl. 2), 2059-2065.

33. Sharma, D., Dangi, C.B.S. \& Kaur, M.A. (2016). Review on pharmacological activities and therapeutic potentials of Ficus religiosa (Pipal). Indian Journal of Applied Research, 6(1), 623-626. 
34. Shree Kumar, P.V. (1998). Six new records of Ficus L. (Moraceae) from Andaman-Nicobar Islands, India. Journal of Economic Taxonomy of Botany, 22, 199-203.

35. Singh, R., Upadhyay, S.K., Rani, A., Kumar, P., Kumar, A. \& Sharma, P. (2019). Ethanobotanical study of Subhartipuram, Meerut, Uttar Pradesh, India. I. Diversity and pharmacological significance of trees. International Journal of Pharmaceutical Research, 11(4), 782-794. https:// doi.org/10.31838/ijpr/2019.11.04.078.

36. Singh, C., Chauhan, N., Rani, A. \& Singh, R. (2020a). Restoration of world heritage site Nanda Devi Biosphere Reserve, Uttarakhand. Journal of Agriculture and Forest Meteorology Research, 3(5), 405-408.

37. Singh, C., Chauhan, N., Upadhyay, S.K. \& Singh, R. (2020b). Phytochemistry and ethnopharmacological study of Adiantum capillus-veneris L. (Maidenhair fern). Plant Archives, 20(2), 3391-3398.

38. Singh, R., Upadhyay, S.K., Rani, A., Kumar, P. \& A. Kumar (2020c). Ethanobotanical study of Subhartipuram, Meerut, Uttar Pradesh, India. II. Diversity and pharmacological significance of shrubs and climbers. International Journal of Pharmaceutical Research, 12(2): 383-393. https://doi.org/10.31838/ijpr/2020.12.02.0050.

39. Singh, R., Upadhyay, S.K., Rani, A., Kumar, P., Sharma, P., Sharma, I., Singh, C., Chauhan, N. \& Kumar, M. (2020d). Ethnobotanical study of weed flora at district Ambala, Haryana, India: Comprehensive medicinal and pharmacological aspects of plant resources. International Journal of Pharmaceutical Research, 12(Spl.1), 19411956. https://doi.org/10.31838/ijpr/2020.SP1.223.

40. Singh, R., Upadhyay, S. K., Tuli, H.S., Singh, M., Kumar, V., Yadav, M., Aggarwal, D. \& Kumar, S. (2020e). Ethnobotany and herbal medicine: Some local plants with anticancer activity. Bulletin of Pure and Applied Sciences (Botany), 39B(1), 57-64. https://doi.org/10.5958/23203196.2020.00009.9.

41. Singh, C., Chauhan, N., Upadhyay, S.K., Singh, R. \& Rani, A. (2021a). The Himalayan natural resources: Chal- lenges and conservation for sustainable development. Journal of Pharmacognosy and Phytochemistry, 10(1), 1643-1648.

42. Singh, R.,Upadhyay, S.K., Singh, B.J., Verma, R., Sharma, I., Sharma, P., Rani, A. \& Singh, C. (2021b). Allelopathic effect of eucalyptus (Eucalyptus camaldulensis Dehnh) on the growth of Aloe vera. Plant Cell Biotechnology and Molecular Biology, 22(21\&22), 94-100.

43. Tiwari, R., Sudhakar, V.J., Srivastava, A.K., Chaudhary, B.L., Murthy, G.V.S. \& Durgapal, A. (2014). Taxonomy, distribution and diversity of Ficus palamata Forssk. Subsp. virgate (Roxb) Browicz (Moraceae) in India. Journal of Threatened Taxa, 6(9), 6172-6185.

44. Tiwari, S. \& Talreja, S. (2020). Do you think disease and disorder are same?-Here is the comparative review to brash up your knowledge. Journal of Pharmacy and Scientific Research, 12(4), 462-468.

45. Tzeng, H.Y., Ou, C.H., Lu, F.Y. \& Wang, C.C. (2009). Pollen morphology of Ficus L. (Moraceae) in Taiwan. Forest Research Quarterly, 31, 33-46.

46. Upadhyay, S.K. (2016a). Anthelmintic and food supplementary conscientiousness of apitoxin in poultry model. Research Journal of Recent Sciences, 5(10), 09-14.

47. Upadhyay, S.K. (2016b). Activity patterns of cell free supernatant of antagonistic microbial strains in rodents hostparasite systems. International Journal of Science and Research, 5(4), 332-336.

48. Upadhyay, S.K. (2016c). Allelopathic activities of specific microbial metabolites in the inland prawn fisheries off eastern Uttar Pradesh, India. International Journal of Scientific Research, 5(2), 415- 416. https://doi.org/10.15 373/22778179.

49. Whistler, W.A. (2000). Tropical ornamentals: A guide. Portland, OR, USA: Timber Press. 542p.

50. Wu, Z., Zhou, Z.K. \& Gilber, M.G. (2003). Moraceae. In: Flora of China (eds. Wu. Z., Raven, P.H. \& Hong, D.Y.). Science Press, Beijing, and Missouri Botanical Garden Press, St. Louis. US. 5, 21-73. 